\title{
Vertical Distribution of Fish Larvae and Its Relation to Water Column Structure in the Southwestern Gulf of California ${ }^{1}$
}

\author{
L. Sánchez-Velasco, ${ }^{2,3}$ S. P. A. Fiménez-Rosenberg, ${ }^{2}$ and M. F. Lavín ${ }^{4}$
}

\begin{abstract}
The seasonal evolution of vertical distribution of fish larvae and its relationship with seasonal stratification, as measured by a quantitative stability parameter, were analyzed for a region off Bahía de La Paz in the southwestern Gulf of California. Samples were obtained with an opening-closing net (505 $\mu \mathrm{m})$ in 50-m depth strata from surface to 200-m depth in May, July, and October 2001 and February 2002. Significant differences in total larval abundance and in dominant species (mesopelagic and epipelagic) were found among strata from May to October. More larvae were found in maximum-stability strata (from $16 \pm 5$ to $48 \pm 17 \mathrm{~m}$ depth) than below the pycnocline (from 100- to 150-m depth). In February, the 100-m-deep surface mixed layer had a weak pycnocline at its base, and no significant difference was found. Results show that vertical distribution of fish larvae in this area depends mainly on the seasonal evolution of the water column structure, with most fish larvae in the pycnocline, at the most stable stratum of the water column.
\end{abstract}

Vertical gRADIENTS IN concentration of fish larvae and zooplankton are usually stronger than horizontal gradients (Ahlstrom 1959, Lasker 1981, Röpke 1993). These vertical gradients may be associated with seasonal changes in the hydrographic structure of the water column, such as temperature and salinity gradients, mixed layer depth, and other

${ }^{1}$ This work was financially supported by Consejo Nacional de Ciencia y Tecnología (CONACyT) (contracts 34071-T and D41881-F), by Coordinación General de Posgrado e Investigación (CGPI)-Instituto Politécnico Nacional (IPN) (projects 20030303 and 20040229), and by Comisión de Operación y Fomento de Actividades Académicas-IPN (COFAA-IPN), Estimulos al Desempeño en Investigación-IPN (EDI-IPN), and Sistema Nacional de Investigadores-CONACyT (SNI-CONACyT). Manuscript accepted 2 October 2006.

${ }^{2}$ Centro Interdisciplinario de Ciencias Marinas (CICIMAR), Departamento de Plancton y Ecología Marina, Avenida Instituto Politécnico Nacional s/n, CP 23000, La Paz, Baja California Sud, México.

${ }^{3}$ Corresponding author (e-mail: 1svelasc@ipn.mx or lsvelasc@prodigy.net.mx).

${ }^{4}$ Centro de Investigación Científica y de Educación Superior de Ensenada (CICESE), Apartado Postal 2732, CP 22830, Ensenada, Baja California, México.

Pacific Science (2007), vol. 61, no. 4:533-548

(C) 2007 by University of Hawai'i Press

All rights reserved changes, as well as biological factors such as behavior and development stage of the species or the vertical distribution of their prey and predators (Lasker 1975, Munk et al. 1989, Moser and Smith 1993).

Studies of vertical distribution of fish larvae in the open sea have shown that the greatest abundance and diversity occur through the pycnocline (layer of sharp change in water density with depth) during periods of strong stratification in the water column or in the surface mixed layer during periods affected by strong winds and tides (e.g., Ahlstrom 1959, Lasker 1975, Loeb and Nichols 1984). However, studies in coastal and reef areas, where the structure of the water column is complex and less constant than in the open sea, have found that vertical distribution of fish larvae depends more on the behavior of each species than on the physics of the water column (Fortier and Harris 1989, Leis 1993).

Even though these studies have generated important information on vertical distribution of fish larvae in specific areas and periods, knowledge on seasonal evolution of vertical distribution of fish larvae in relation to water column structure in tropical regions is still incipient. In particular, although it has been a long time since Sverdrup (1953) linked 
spring phytoplankton bloom to stability through his critical depth hypothesis and Lasker $(1975,1981)$ postulated that a stable environment promotes aggregation of fish larvae and their prey, thereby enhancing larval survival, studies that relate vertical distribution of fish larvae to stability measurements of the water column are practically nonexistent. Because the hypotheses described in those studies were designed for midlatitude conditions, it is particularly interesting to know whether they apply to vertical distribution of larvae in tropical regions such as the Gulf of California.

The southern Gulf of California is characterized by strong seasonal variation in the structure of the water. In spring and summer the stratification reaches the surface, but in winter the surface mixed layer can reach down to 100-m depth (e.g., Castro et al. 2000, Amador-Buenrostro et al. 2003, Lavín and Marinone 2003, Trasviña-Castro et al. 2003). Bahía de La Paz (Figure 1) is the largest coastal embayment on the southwestern side of the Gulf of California and is connected with the gulf through two entrances. The main entrance (northeast of the bay) is wide $(37 \mathrm{~km})$ and deep $(250 \mathrm{~m})$, whereas the smaller entrance (south of the bay), is narrow $(7 \mathrm{~km})$ and shallow $(19 \mathrm{~m})$. In association with the physiography of the main entrance of the bay, a high diversity and abundance of fish species of commercial and ecological importance, both in larval and adult stages, have been recorded (e.g., Balart et al. 1997, González-Armas 2002, Muhlia-Melo et al. 2003, Sánchez-Velasco et al. 2004).

Because of the continuous interaction between the main entrance of the bay and the gulf (Trasviña-Castro et al. 2003, SánchezVelasco et al. 2006), it was expected that fish larvae of a large number of species would be distributed vertically as a function of the seasonal changes of the water column structure (e.g., maximum stability, pycnocline and surface mixed layer depth). The aim of this study is to make an initial description of vertical distribution of fish larvae in the southwestern gulf just outside the main entrance to Bahía de La Paz, its seasonal evolution, and its relationships with the vertical structure of the water column. A quantitative measure of stability was used to link the seasonal changes of the vertical distribution of larvae to stratification.

\section{MATERIALS AND METHODS}

Physical and zooplankton data were obtained at nine stations on board the R/V Francisco de Ulloa (CICESE) during four oceanographic cruises, 19 to 23 May, 21 to 25 July, and 26 to 30 October 2001 and 11 to 15 February 2002 , in the vicinity of the main entrance to Bahía de la Paz (Figure 1).

Vertical profiles of temperature and conductivity were obtained at each station with a conductivity, temperature, depth profiler (model 911 plus, Sea-Bird Electronics, Bellevue, Washington). The data were processed with the manufacturer's software to obtain temperature and salinity profiles interpolated to 1-m intervals. A Hanning filter was applied five times to the potential temperature (T) and salinity (S) profiles before calculating the potential density anomaly, $\gamma(z)=\rho(z)-1,000$, where $\rho$ is density and $z$ is depth, which was then used to calculate the stability parameter, $E(z)=-\rho^{-1} d \rho / d z$; the latter is a local measure of stratification, being maximum where the pycnocline is the strongest.

The depth of the surface mixed layer $\left(\mathrm{H}_{\text {mix }}\right)$, the range of the pycnocline, and the depth of maximum stability $\left(Z_{\mathrm{Emax}}\right)$ were estimated by examination, for each station, of the profiles $\mathrm{T}(z), \mathrm{S}(z), \gamma(z)$, and, especially, $\mathrm{E}(z)$. Mean profiles of those variables were also obtained for each cruise.

The zooplankton samples were collected during both daylight and darkness with an opening-closing conical zooplankton net with $50-\mathrm{cm}$ mouth diameter, $250-\mathrm{cm}$ mesh length, and $505-\mu \mathrm{m}$ mesh size, at four depth strata: 0-50 m, 50-100 m, 100-150 m, and 150$200 \mathrm{~m}$. The depth of each stratum was calculated by the cosine of the wire angle method following the standard specifications of Smith and Richardson (1979). The mean bottom depth was $250 \mathrm{~m}$. The deepest interval was not sampled in February 2002 due to technical problems (the cable had to be cut during 


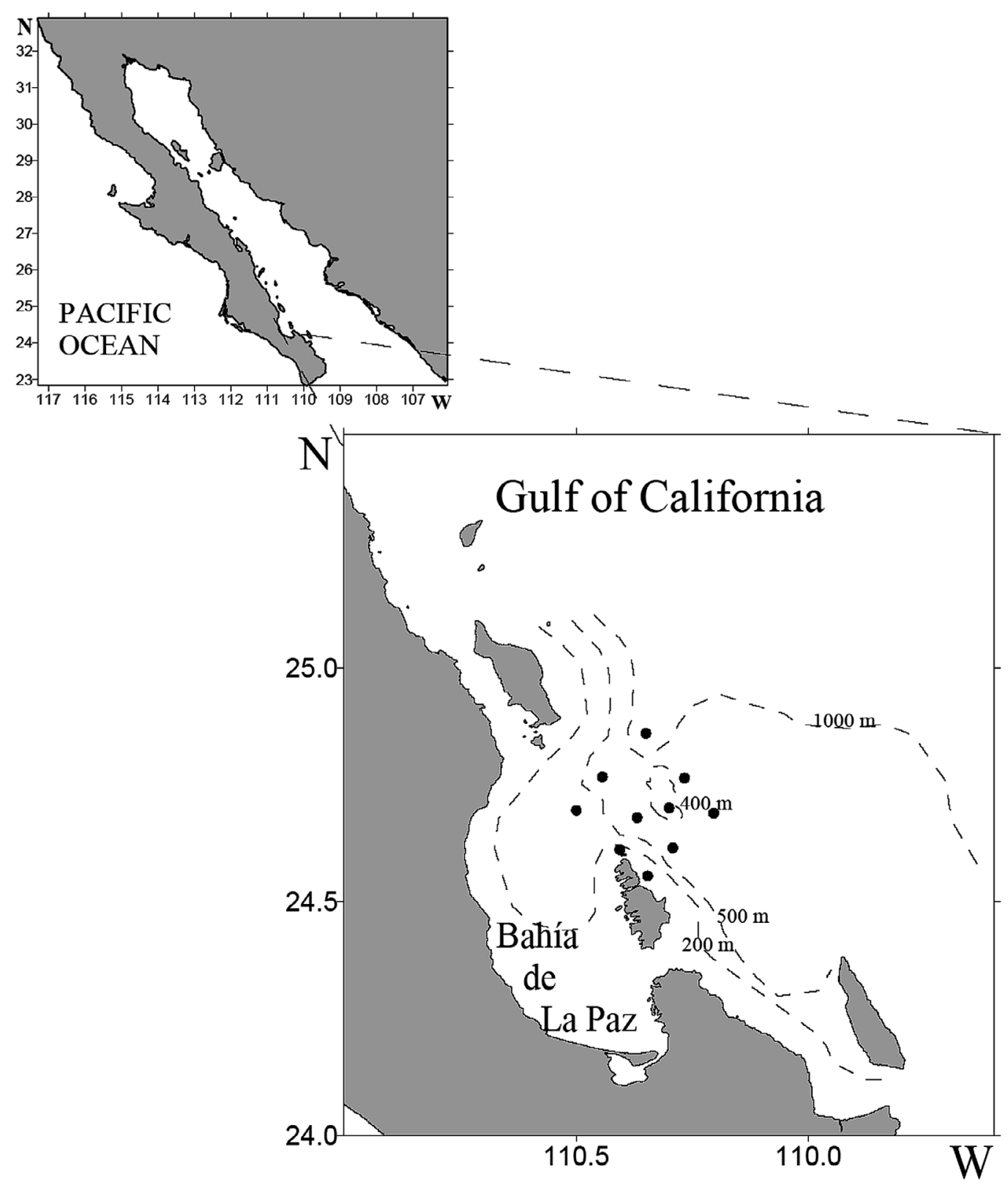

FIGURE 1. Location of the study area and sampling stations.

the cruise). The filtered water volume was calculated using calibrated flowmeters placed in the mouth of the nets. Each sample was fixed with $5 \%$ formalin buffered with sodium borate. Larvae were removed from the sam- ples and identified according to the descriptions of Moser (1996). Larval abundance was standardized to number of larvae per $10 \mathrm{~m}^{2}$.

Because of the great variance characteristic of the zooplankton organisms, which are dis- 
TABLE 1

Total Larval Abundance between Light and Darkness Hours off Bahía de La Paz (Gulf of California) (Nonparametric Mann-Whitney Test [Mann and Whitney 1947])

\begin{tabular}{lccccc}
\hline \hline & \multicolumn{5}{c}{ Water Column Level (m) } \\
\cline { 2 - 5 } Cruise & $0-50$ & $50-100$ & $100-150$ & $150-200$ & All Levels \\
\hline May 2001 & $5(1 / 14)$ & $2(1 / 14)$ & $5(1 / 14)$ & $2(1 / 14)$ & $2(1 / 14)$ \\
July 2001 & $0(0 / 12)$ & $0^{*}(2 / 16)$ & $2(2 / 16)$ & $3(0 / 12)$ & $3(2 / 16)$ \\
October 2001 & $1(0 / 12)$ & $3(2 / 16)$ & $5(2 / 16)$ & $4(0 / 12)$ & $3(2 / 16)$ \\
February 2002 & $13(1 / 15)$ & $6(2 / 18)$ & $13(2 / 18)$ & & $7(2 / 18)$ \\
\hline
\end{tabular}

Note: Numbers within parentheses represent critical values (minimum/maximum). Asterisk indicates value outside the critical range that was significantly different $(P \leq .05)$.

tributed in patches in the sea (Margalef 1968), the nonparametric Mann-Whitney test (Sokal and Rohlf 1979) was used to assess the statistical significance of differences of the total larval abundance between day and night hours and among the different depth strata in each sampled period. There was no significant difference in total larval abundance between day and night hours in all cases $(P>.05)$, except in one stratum in July (Table 1).

Similarities among the different depth strata were based on taxa with a frequency of occurrence $\geq 5 \%$ in each period. To reduce the weight of the most abundant species, the standardized data were fourth-root transformed. Groups of strata were defined using the Bray-Curtis dissimilarity index, a technique that is not affected by multiple absences and gives more weight to abundant species than to rare ones (Bray and Curtis 1957, Field et al. 1982). Dendrograms were made by the flexible agglomerative clustering method (Sokal and Sneath 1963).

\section{RESULTS}

The T-S diagram and the average profiles $\mathrm{T}(z), \mathrm{S}(z), \gamma(z)$ (Figure 2) show the usual seasonal pattern of the Gulf of California hydrography (Castro et al. 2000, Lavín and Marinone 2003). The 0 - to $150-\mathrm{m}$ layer was occupied most of the year by Gulf of California Water $\left(\mathrm{GCW} \mathrm{S}>35\right.$ ups, $\mathrm{T}>12^{\circ} \mathrm{C}$ ), except in October when Tropical Surface Water (TSW $\mathrm{S}<35$ ups, $\mathrm{T}>18^{\circ} \mathrm{C}$ ) completely displaced the GCW in the $0-$ to $60-\mathrm{m}$ layer. Subtropical Subsurface Water (StSsW) was present from 150 to $500 \mathrm{~m}$, and Pacific Intermediate Water (PIW) in the remainder of the sampled water column. The seasonal evolution of stratification in the top $200 \mathrm{~m}$ of the water column, described here, is based on the mean stability profiles $\mathrm{E}(z)$ (Figure 3).

In May, some stratification was present from the surface to $100 \mathrm{~m}$; the high values of the stability parameter $\mathrm{E}(z)$ in the upper 50 $\mathrm{m}\left(\mathrm{Z}_{\mathrm{Emax}}=16 \pm 5 \mathrm{~m}\right)$ indicate that the pycnocline covered from near the surface to $\sim 40 \mathrm{~m}$. In half of the stations the surface mixed layer depth was $10 \mathrm{~m}$, and in the other half it was $0 \mathrm{~m}$; in the latter, the surface salinity $\left(\mathrm{S}_{\mathrm{s}}=35.31\right)$ was the highest of the study (Table 2).

In this period, fish larvae of 27 species in 19 families were collected (Appendix). Significant differences between the total larval abundance of the 0 - to $50-\mathrm{m}$ and $100-$ to $150-\mathrm{m}$ strata and between the $0-$ to $50-\mathrm{m}$ and 150 - to $200-\mathrm{m}$ strata were found $(P<.05)$ (Table 3). The most abundant species were Vinciguerria lucetia (Phosichthyidae) (65\%), Diogenichthys laternatus (Myctophidae) (11\%), and Opisthonema spp. (Clupeidae) (7\%) accounting for $83 \%$ of the fish larvae caught in the cruise. The first two species were distributed over the entire sampled water column, whereas Opisthonema spp. larvae were found only in the upper $50 \mathrm{~m}$. The larval abundance of $V$. lucetia was significantly different between the 0 - to $50-\mathrm{m}$ and the $100-$ to $200-\mathrm{m}$ strata $(P<.05)$ (Figure 4). Although the highest mean larval abundance of this species was in the $50-$ to $100-\mathrm{m}$ stratum, it was not 

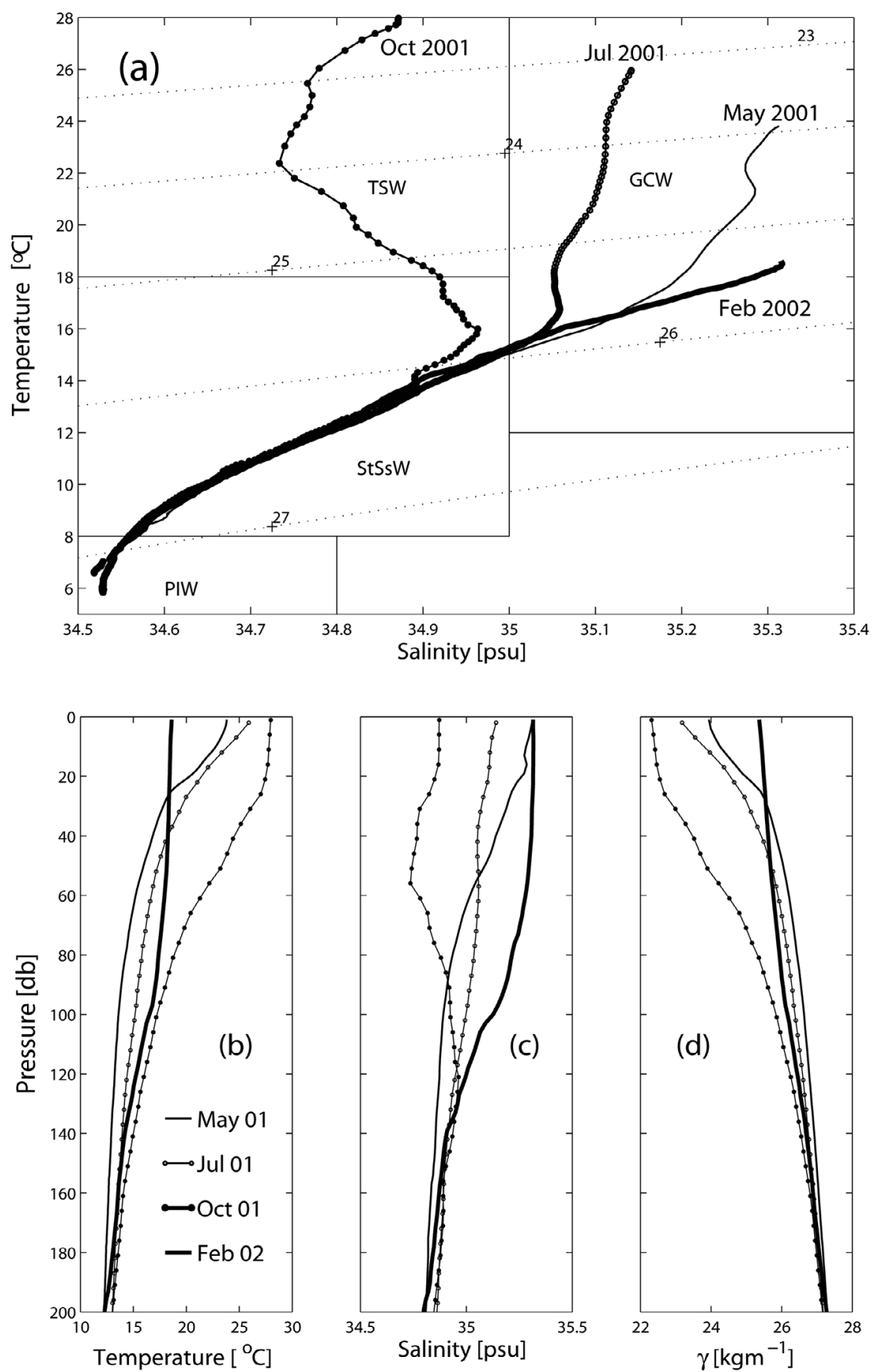

FIGURE 2. T-S diagram $(a)$ and average temperature, salinity, and density profiles $(b, c$, and $d)$ from conductivity, depth, and temperature data obtained during May, July, and October 2001 and February 2002. GCW, Gulf of California Water; TSW, Tropical Subtropical Water; StSsW, Subtropical Subsurface Water; and PIW, Pacific Intermediate Water. 


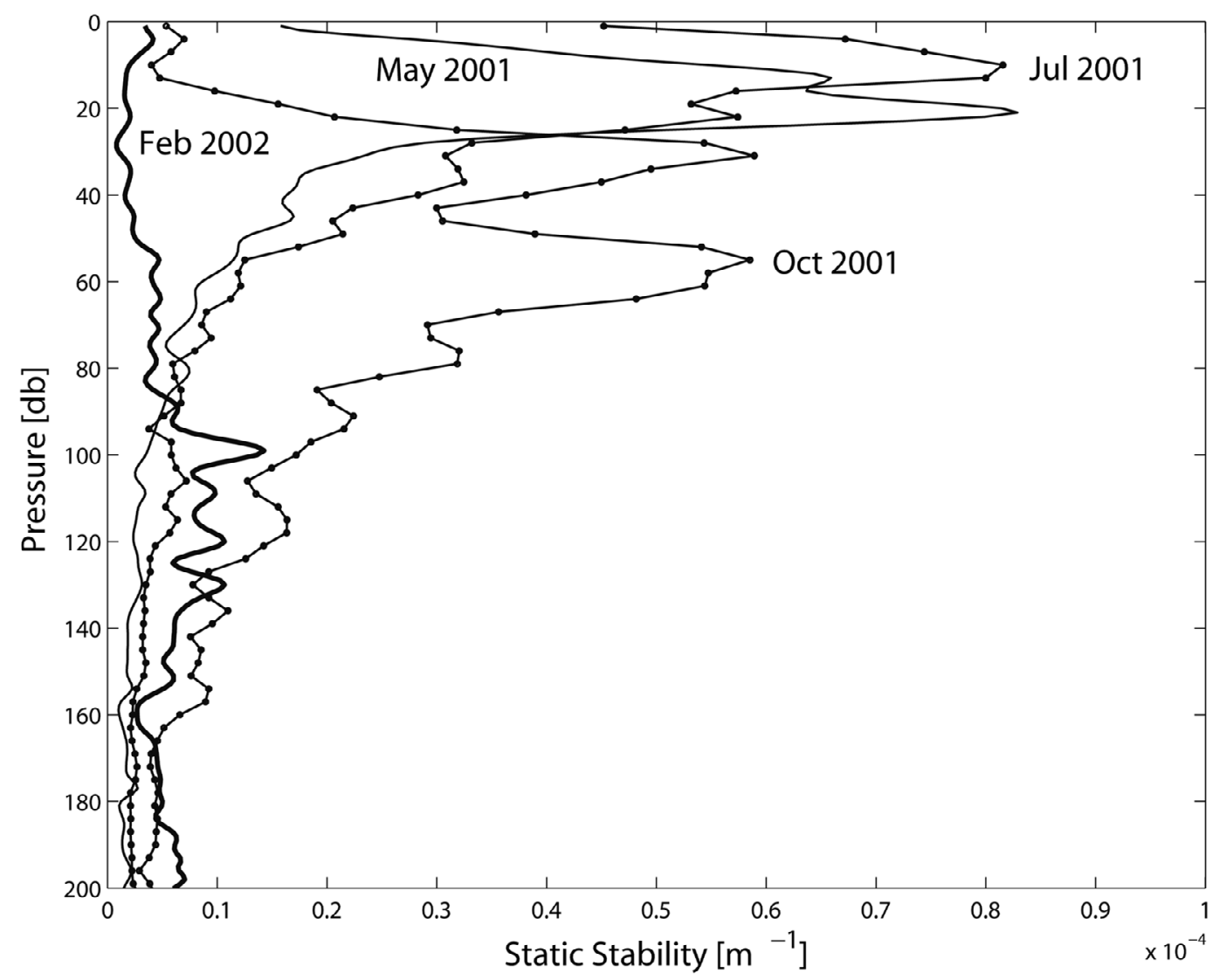

FIGURE 3. Average profiles of static stability from conductivity, depth, and temperature data obtained off Bahía de La Paz (Gulf of California) during May, July, and October 2001 and February 2002.

TABLE 2

Mean Features of Water Column Structure off Bahía de La Paz (Gulf of California) during May, July, and October 2001 and February 2002

\begin{tabular}{lllll}
\hline \hline Cruise & May 2001 & July 2001 & October 2001 & February 2002 \\
\hline $\mathrm{H}_{\text {mix }}(\mathrm{m})$ & $0(5.6 \pm 5)$ & $0(4.4 \pm 9)$ & $17 \pm 8.3$ & $79 \pm 18$ \\
$\mathrm{~S}_{\mathrm{s}}(\mathrm{psu})$ & $35.31 \pm 0.08$ & $35.14 \pm 0.06$ & $34.87 \pm 0.2$ & $35.31 \pm 2.2$ \\
$\mathrm{~T}_{\mathrm{s}}\left({ }^{\circ} \mathrm{C}\right)$ & $23.79 \pm 0.92$ & $25.90 \pm 1.4$ & $28.0 \pm 0.2$ & $18.6 \pm 0.3$ \\
$\mathrm{Z}_{\text {Emax }}(\mathrm{m})$ & $16.5 \pm 4.9$ & $12.4 \pm 7.3$ & $48 \pm 17$ & $100 \pm 27$ \\
Range of pycnocline $(\mathrm{m})$ & $0-40$ & $0-40$ & $30-80$ & $100-110$ \\
\hline
\end{tabular}

Note: $\mathrm{S}_{\mathrm{s}}$ and $\mathrm{T}_{\mathrm{s}}$, respectively, are salinity and temperature at $1-\mathrm{m}$ depth; $\mathrm{H}_{\operatorname{mix}}$ is the surface mixed layer depth; $\mathrm{Z}_{\mathrm{Emax}}$ is the depth of the maximum value of the stability parameter. All $\pm S D$ of the estimates from the individual profiles. 
TABLE 3

Total Larval Abundance among the Different Depth Sampling Strata off Bahía de La Paz (Gulf of California) (Nonparametric Mann-Whitney Test [Mann and Whitney 1947])

\begin{tabular}{llcccrr}
\hline \hline & \multicolumn{5}{c}{ Water Column Level (m) } \\
\cline { 2 - 6 } Cruise & $0-50 /$ & $0-50 /$ & $0-50 /$ & $50-100 /$ & $50-100 /$ & $100-150 /$ \\
May 2001 & $50-100$ & $100-150$ & $150-200$ & $100-150$ & $150-200$ & $150-200$ \\
\hline July 2001 & $30(8 / 34)$ & $30^{*}(6 / 29)$ & $15^{*}(0 / 14)$ & $23(5 / 25)$ & $9(0 / 12)$ & $5(0 / 10)$ \\
October 2001 & $49(15 / 48)$ & $32(12 / 42)$ & $47^{*}(12 / 42)$ & $13(8 / 34)$ & $27(8 / 34)$ & $28(7 / 29)$ \\
February 2002 & $16(5 / 25)$ & $55(21 / 60)$ & $37^{*}(9 / 36)$ & $46(21 / 60)$ & $37^{*}(9 / 36)$ & $27(9 / 36)$ \\
\hline
\end{tabular}

Note: Numbers within parentheses represent critical values (minimum/maximum). Asterisks indicate values outside the critical range that were significantly different $(P \leq .05)$.

significantly different from those of the other strata due to high variance. The BrayCurtis index clearly defined two groups of strata: the surface stratum (0- to 50 -m depth) and the strata from 50- to 200-m depth (Figure 5), in line with the significance test.

In July, the stratification again reached to the surface $\left(\mathrm{H}_{\text {mix }} \sim 0\right.$ almost everywhere) and was present down to $100-\mathrm{m}$ depth. The strongest stability (that is, the pycnocline) was found in the upper $40 \mathrm{~m}$ $\left(\mathrm{Z}_{\mathrm{Emax}}=12 \pm 7 \mathrm{~m}\right)$ (Table 2).

In this period, fish larvae of 46 species in 31 families were collected (Appendix). Significant differences between the total larval abundance of the 0 - to $50-\mathrm{m}$ and 150 - to $200-\mathrm{m}$ strata were found $(P<.05)$ (Table $3)$. The most abundant species were $V$. lucetia (33\%), Triphoturus mexicanus (Myctophidae) $(30 \%)$, and D. laternatus (16\%). These three species were found over the entire sampled water column. The abundance of $V$. lucetia larvae was significantly different between the 0 - to $50-\mathrm{m}$ and 50 - to $100-\mathrm{m}$ levels and between the 0 - to $50-\mathrm{m}$ and $150-$ to $200-\mathrm{m}$ levels $(P<.05)$ (Figure 4). The Bray-Curtis index did not define strata groups as in the other periods, but most of the 0 - to $100-\mathrm{m}$ strata were separated from the 100- to 200$\mathrm{m}$ strata (Figure 5).

In October, the surface mixed layer was $20 \mathrm{~m}$ deep, a mean pycnocline was present from 30-m to 80-m depth (although there was some stratification down to $125 \mathrm{~m}$ ), and there were two stability peaks, at 30 and $54 \mathrm{~m}$.
The lowest $\mathrm{S}_{\mathrm{s}}$ (34.87) was observed in this period, with minimum salinity cores $(\sim 34.74)$ at $40-$ to $60-\mathrm{m}$ depth as marked by the two peaks in $\mathrm{E}(z)$ (Table 2).

Fish larvae of 88 species in 47 families were collected (Appendix). Significant differences were found between the total larval abundance of the 0 - to $100-\mathrm{m}$ and $15-$ to 200-m strata $(P<.05)$ (Table 3$)$. The most abundant species were $V$. lucetia (23\%), Benthosema panamense (Myctophidae) (20\%), and D. laternatus $(5 \%)$. These species were found over the entire sampled water column. The abundance of $B$. panamense and $V$. lucetia larvae was significantly different between the 0 - to $100-\mathrm{m}$ and the 150 - to $200-\mathrm{m}$ strata $(P>.05)$ (Figure 4). The Bray-Curtis index defined a large group for the strata from 0 - to $100-\mathrm{m}$ depth (Figure 5), and most of the strata from 150- to 200-m depth were not clustered.

In February, stratification was weak in the top $200 \mathrm{~m}$, and the density step across the pycnocline was very small. The surface mixed layer was $100 \mathrm{~m}$ deep, and the maximum stability was located at the base of the mixed layer. The lowest $T_{s}$ and a $S_{s}$ as high as in May 2001 (35.31) were recorded in this period (Table 2).

Fish larvae of 15 species in 11 families were collected (Appendix). No significant differences among total larval abundance of the sampled strata were found $(P>.05)$ (Table $3)$. The most abundant species were Sardinops sagax (29\%) (Clupeidae), D. laternatus (24\%), 


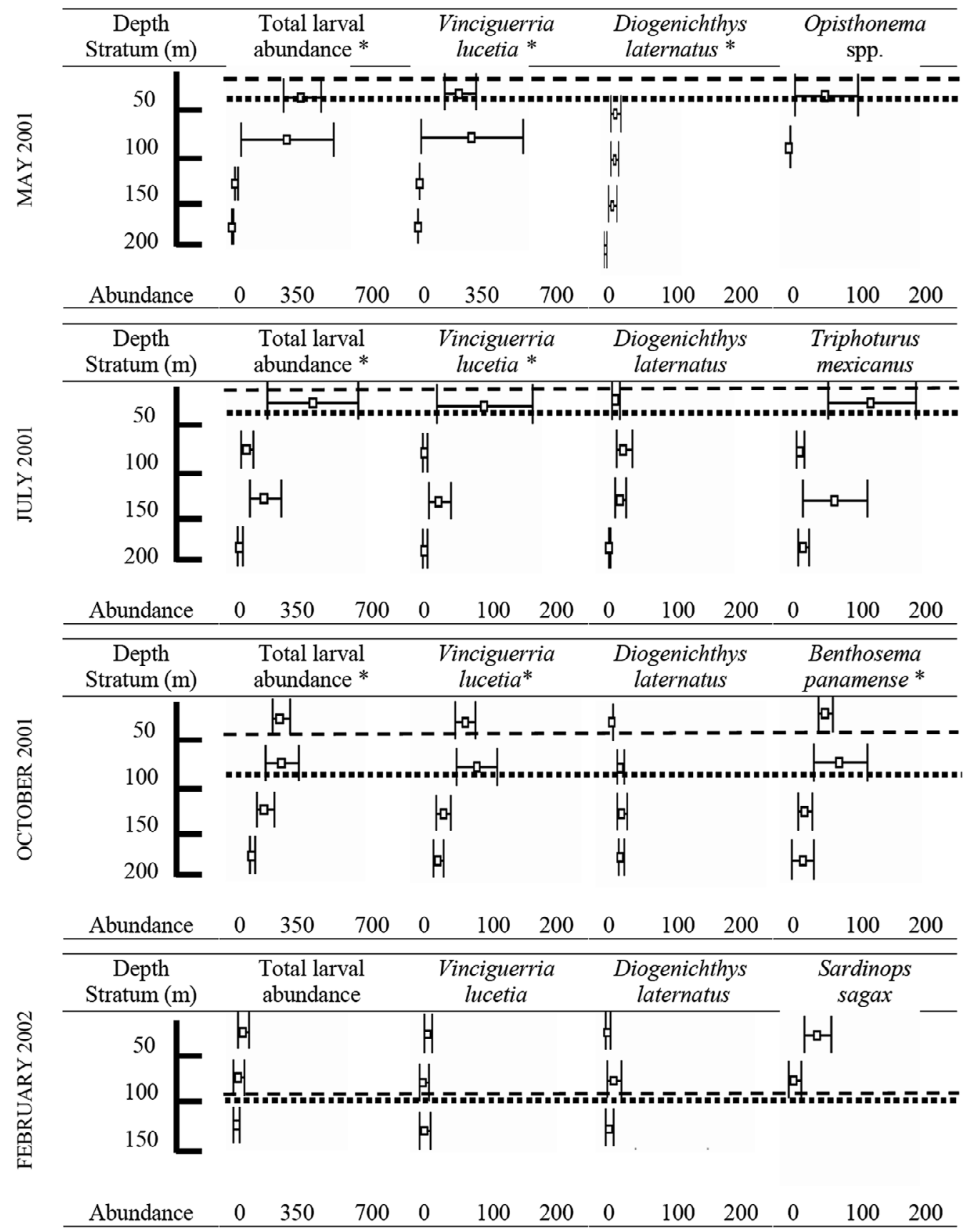

H Standard error; $\square$ Mean.

FIgURE 4. Vertical distribution of total larval abundance (larvae per $10 \mathrm{~m}^{2}$ ) and the most abundant species off Bahía de La Paz (Gulf of California) during May, July, and October 2001 and February 2002. Asterisks indicate significant differences; dashed line represents depth of the maximum stability; dotted line represents depth of the maximum pycnocline. 


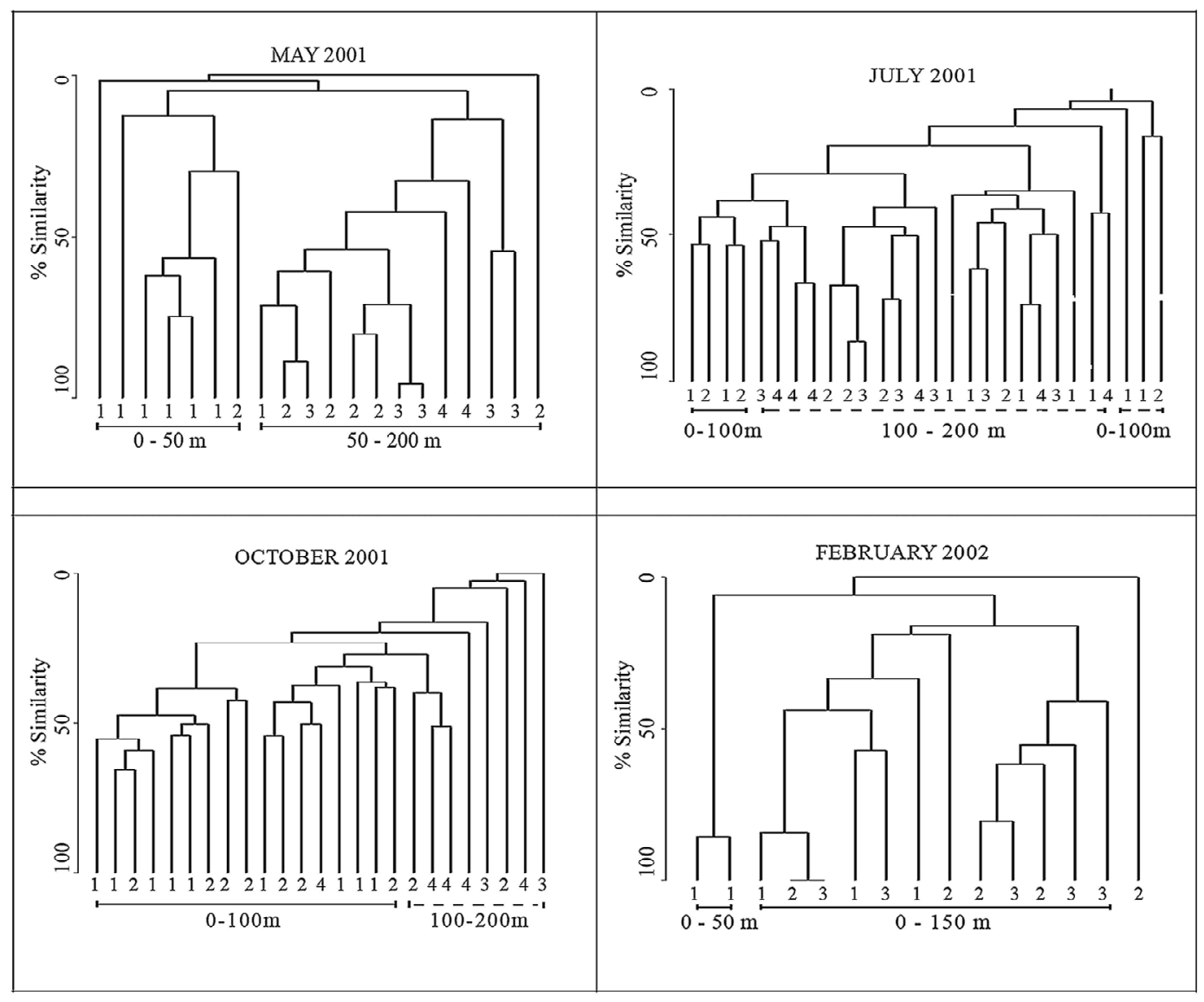

Figure 5. Dendrograms of groups of strata defined by the Bray-Curtis index and flexible agglomerative method off Bahía de La Paz (Gulf of California) during May, July, and October 2001 and February 2002. 1, sampling stations of the stratum of 0 - to $50-\mathrm{m}$ depth; 2 , stratum of 50- to $100-\mathrm{m}$ depth; 3 , stratum of 100 - to $150-\mathrm{m}$ depth; 4 , stratum of 150- to 200-m depth.

and $V$. lucetia (20\%). Larvae of D. laternatus and $V$. lucetia were found over the entire sampled water column, and most of the sardine larvae were in the upper $50 \mathrm{~m}$. No significant differences were found among the sampled strata $(P>.05)$ (Figure 4). The Bray-Curtis index defined a large group including strata from 0 - to $150-\mathrm{m}$ depth, in line with the significance test (Figure 5).

\section{DISCUSSION}

Results show that vertical distribution of the fish larvae in the area just outside the main entrance to Bahía de La Paz is related to seasonal evolution of the vertical structure of the water column. Total larval abundance and the most abundant and frequent species were significantly higher in the most stable stratum of the water column than below the pycnocline.

In May, when the pycnocline and $\mathrm{Z}_{\mathrm{Emax}}$ were both found in the top $50 \mathrm{~m}$, total larval abundance and abundance of $V$. lucetia larvae were significantly higher in the 0 to $50-\mathrm{m}$ depth stratum than in the 100 - to $150-\mathrm{m}$ and 150- to 200-m strata. In July, when stratification was similar to that in May, total larval abundance and abundance of $V$. lucetia 
larvae were significantly higher in the 0 - to $50-\mathrm{m}$ stratum than in the 150 - to $200-\mathrm{m}$ stratum. In October, when the pycnocline extended from 30- to 80-m depth and the two $Z_{\text {Emax }}$ were present in the upper $100 \mathrm{~m}$, there was a coincident significant difference in total larval abundance and in abundance of $B$. panamense and $V$. lucetia larvae between the 0 - to $100-\mathrm{m}$ interval and the 150 - to $200-\mathrm{m}$ stratum. In February, when the mixed layer was $100 \mathrm{~m}$ deep and the pycnocline was very weak, no significant differences were found in total larval abundance nor in the larvae of the most abundant species in the sampled strata (0- to 150 -m depth).

Although there are no previous studies that relate vertical distribution of fish larvae to evolution of the structure of the water column in the Gulf of California, relationships between the pycnocline and high abundance of fish larvae recorded in this study tend to be in agreement with previous work elsewhere. Loeb and Nichols (1984), who analyzed the vertical distribution of zooplankton in general at one site in the eastern tropical Pacific during summer, noted that maximum ichthyoplankton abundance and diversity occurred in the pycnocline; the studies of Moser and Smith (1993) in the California Current found the highest density of fish larvae to be associated with the interface between the mixed layer and the pycnocline in summer; and Röpke (1993), in the northern Arabian Sea during an intermonsoon period (March-June), reported that fish larvae of the most abundant mesopelagic species were closely associated with the pycnocline but less abundant mesopelagic species were found below it.

Those previous works did not take into account relationships between $Z_{\text {Emax }}$ and larval fish distribution, but we suggest with our results that there are favorable conditions for most fish larvae through the pycnocline and particularly in the strata where $Z_{\mathrm{Emax}}$ was registered. The fundamental reason for this result cannot be investigated with the data presented here. Among the possible hypotheses that can be tested are Sverdrup's critical depth hypothesis (Sverdrup 1953) and Lasker's stability hypothesis (Lasker 1975, 1981), which suggest the importance of water column stability in the life cycles of planktonic species. In the most stable zone of the water column, interaction of optimal concentrations of nutrients, oxygen, and solar radiation results in phytoplankton blooms and promotes prey-predator aggregations: in this case, fish larvae with their prey, a prime requisite for larval survival. We hope that future work will address the subject.

In particular, vertical distribution of the sardine larvae in this study, Ophisthonema spp. in May and S. sagax in February, indicates that even though these species were above or in the steepest gradient of the pycnocline, they were concentrated in the uppermost stratum of the water column $(\leq 50-\mathrm{m}$ depth), apparently unaffected by the position or thickness of the pycnocline or the mixed layer depth. Ahlstrom (1959) and Moser and Smith (1993) found that $S$. sagax larvae occur predominantly in the upper part of the mixed layer during periods of strong winds in the California Current region. ArmentaMartínez (2004) observed great abundance of sardine larvae (Ophisthonema spp. in summer and S. sagax in winter) at 10-m depth inside Bahía de La Paz. This suggests that the larvae of S. sagax and Ophistbonema spp. consistently inhabit the upper meters of the water column, at least until the larval postflexion phase.

The fact that larval movements in relation to the daily cycle were not evident in this study may be related to the thickness of the sampled strata (i.e., intervals of $50 \mathrm{~m}$ ). Brewer and Kleppel (1986), Leis (1986), and Fortier and Harris (1989), who made studies of vertical distribution of fish larvae in narrower strata $(<10-\mathrm{m}$ depth) in shallow areas, detected variations in relation to the daily cycle. But in all of those studies the water column did not present substantial vertical thermal or salinity gradients, in contrast with the strong stratification of the water column observed in the Gulf of California. It is possible that significant larval movements would be detected in relation to the daily cycle if narrower strata had been sampled.

The intrusion of Tropical Surface Water (TSW) that was recorded in the study area in October 2001 coincided with the highest specific richness of fish larvae of all cruises, 
being almost six times richer than in February. This intrusion of TSW is part of the seasonal pattern of the gulf's hydrography, being evident in summer months due to the poleward intrusion of TSW, probably through the poleward Costa Rica Coastal Current or Mexican Current (Kessler 2006, Lavín et al. 2006).

\section{CONCLUSIONS}

The vertical distribution of fish larvae off Bahía de La Paz is closely related to the seasonal changes of the water column structure, with most fish larvae concentrated in the stratum of maximum stability, which covered from the surface to $\sim 40 \mathrm{~m}$ in the spring and summer of 2001 (no surface mixed layer), from 30 to $80 \mathrm{~m}$ in the fall of 2001 , and was very weak and deep $(\sim 100 \mathrm{~m})$ in winter of 2001-2002. In addition, the fall 2001 data showed the seasonal invasion of TSW, both in the thermohaline characteristics and in the high specific richness of fish larvae.

\section{ACKNOWLEDGMENTS}

Special acknowledgment is given to the scientific and technical staff that took part in the cruises on board the R/V Francisco de Ulloa, particularly to Alma Rosa Padilla, Instituto de Ciencias del Mar y Limnologia Universidad Autónoma de México; Juan Francisco Moreno, CICESE; and Bernardo Shirasago, CICIMAR. Physical data processing was done by V. Godínez. M.F.L. worked on this article while at Scripps Institution of Oceanography-University of California San Diego as recipient of a UCMEXUS (University of California Institute for Mexico and the United States)-CONACyT sabbatical scholarship. L.S.V gives thanks to Instituto Politecnico Nacional (SIP, EDI, and COFAA) and SEP-CONACyT project 46349.

\section{Literature Cited}

Ahlstrom, E. H. 1959. Vertical distribution of pelagic fish eggs and larvae off California and Baja California. Fish. Bull. 60:107146.

Amador-Buenrostro, A., A. Trasviña-Castro, A. Muhlia-Melo, and M. Argote-Espinoza.
2003. Influence of EBES Seamount and Farallón Basin on coastal circulation in the Gulf of California, Mexico. Geofis. Int. 42:407-418.

Armenta-Martínez, L. F. 2004. Composición y distribución de larvas de peces en la Bahía de La Paz (Golfo de California) durante épocas climáticas extremas. Profesional thesis, Universidad Autónoma de Baja California Sur, La Paz, México.

Balart, E. F., J. L. Castro-Aguirre, and F. de la Chica-Bonilla. 1997. Análisis comparativo de las comunidades ícticas de fondos blandos y someros de la Bahía de la Paz B.C.S. Pages 163-176 in R. Urban and M. Ramírez, eds. La Bahía de La Paz: Investigación y conservación. Universidad Autónoma de Baja California Sur-Centro Interdisciplinario de Ciencias Marinas, México.

Bray, J. R., and J. T. Curtis. 1957. An ordination of the upland forest communities of southern Wisconsin. Ecol. Monogr. 27:235-249.

Brewer, G. D., and G. S. Kleppel. 1986. Diel vertical distribution of fish larvae and their prey in nearshore waters of southern California. Mar. Ecol. Prog. Ser. 27:217-226.

Castro, R., A. S. Mascarenhas, R. Durazo, and C. A. Collins. 2000. Seasonal variation of the temperature and salinity at the entrance to the Gulf of California, Mexico. Cienc. Mar. 26:561-583.

Field, J. G., K. R. Clarke, and M. Warwick. 1982. A practical strategy for analysing multispecies distribution patterns. Mar. Ecol. Prog. Ser. 8:37-52.

Fortier, L., and R. P. Harris. 1989. Optimal foraging and density-dependent competition in marine fish larvae. Mar. Ecol. Prog. Ser. 51:19-33.

González-Armas, R. 2002. Agregación de larvas de peces en el Bajo Espíritu Santo en el Golfo de California, sus cambios en los patrones de distribución y los procesos oceanográficos que los influyen. Ph.D. thesis, Centro de Investigaciones Biológicas del Noroeste S.C., La Paz, México.

Kessler, W. S. 2006. The circulation of the eastern tropical Pacific: A review. Prog. Oceanogr. 69:181-217.

Lasker, R. 1975. Field criteria for survival of 
anchovy larvae: The relation between inshore chlorophyll maximum layer and successful first feeding. Fish. Bull. 73:453462.

1981. The role of a stable ocean in larval fish survival and subsequent recruitment. Pages 80-87 in R. Lasker, ed. Marine fish larvae: Morphology, ecology, and relation to fisheries. Washington Sea Grant Program, University of Washington Press, Seattle.

Lavín, M. F., E. Beier, J. Gómez-Valdés, V. M. Godínez, and J. García. 2006. On the summer poleward coastal current off SW México. Geophys. Res. Lett. 33, L02601, doi:10.1029/2005GL024686.

Lavín, M. F., and S. G. Marinone. 2003. An overview of the physical oceanography of the Gulf of California. Pages 173-204 in O. Velasco-Fuentes, J. Sheinbaum, and J. L. Ochoa de la Torre, eds. Nonlinear processes in geophysical fluid dynamics. Kluwer Academic Publishers, Dordrecht.

Leis, J. M. 1986. Vertical and horizontal distribution of fish larvae near coral reefs at Lizard Island, Great Barrier Reef. Mar. Biol. (Berl.) 90:505-516.

1993. Larval fish assemblages near Indo-Pacific coral reefs. Bull. Mar. Sci. 53:362-392.

Loeb, V. J., and A. Nichols. 1984. Vertical distribution and composition of ichthyoplankton and invertebrate zooplankton assemblages in the eastern tropical Pacific. Biol. Pesq. 13:39-66.

Mann, H. B., and D. R. Whitney. 1947. On a test of whether one of two random variables is stochastically larger than the other. Ann. Math. Stat. 18:50-60.

Margalef, R. 1968. Perspectives in ecological theory. University of Chicago Press, Chicago.

Moser, H. G., ed. 1996. The early stages of fishes in the California Current Region. Calif. Coop. Oceanic Fish. Invest. Atlas No. 33.

Moser, H. G., and P. E. Smith. 1993. Larval fish assemblages of the California Current Region and their horizontal and vertical distribution across a front. Bull. Mar. Sci. 53:645-691.
Muhlia-Melo, A., P. Klimley, R. GonzálezArmas, S. Jorgensen, A. Trasviña-Castro, J. Rodríguez-Romero, and A. Buenrostro. 2003. Pelagic fish assemblages of the Espiritu Santo Seamount in the Gulf of California during El Niño 1997-1998 and non-El Niño conditions. Geofis. Int. 42:473-481.

Munk, P., T. Kiorboe, and L. Christensen. 1989. Vertical migrations of herring, Clupea barengus, larvae in relation to light and prey distribution. Environ. Biol. Fishes 26:87-96.

Röpke, A. 1993. Do larvae of mesopelagic fishes in the Arabian Sea adjust their vertical distribution to physical and biological gradients? Mar. Ecol. Prog. Ser. 101:223235.

Sánchez-Velasco, L., E. Beier, C. AvalosGarcía, and M. Lavín. 2006. Larval fish assemblages and geostrophic circulation in Bahia de la Paz and the surrounding southwestern region of the Gulf of California. J. Plankton Res. 28:1-18.

Sánchez-Velasco, L., S. P. A. JiménezRosenberg, B. Shirasago, and M. ObesoNieblas. 2004. Distribution and abundance of fish larvae in Bahía de La Paz (Gulf of California) and their relation to hydrographic variability during summer (19971998). Deep-Sea Res. 51:723-737.

Smith, P. E., and S. L. Richardson. 1979. Tecnicas modelo para prospecciones de huevos y larvas de peces pelágicos. FAO Doc. Tec. Pesca 175.

Sokal, R. R., and F. Rohlf. 1979. Biometría: Principios y métodos estadísticos en la investigación biológica. $\mathrm{H}$. Blume, Madrid.

Sokal, R. R., and P. H. Sneath. 1963. Principles of numerical taxonomy. W. H. Freeman and Co., San Francisco.

Sverdrup, H. U. 1953. On conditions for the vernal blooming of phytoplankton. J. Cons. Int. Explor. Mer 18:287-295.

Trasviña-Castro, A. G., A. Gutiérrez de Velasco, R. Valle-Levinson, R. González, A. Muhlia, and M. A. Cosio. 2003. Hydrographic observations of the flow in the vicinity of a shallow seamount top in the Gulf of California. Estuarine Coast. Shelf Sci. 57:149-162. 
Appendix

List of Species Identified off Bahía de La Paz (Gulf of California) during May, July, and October 2001 and February 2002

\begin{tabular}{|c|c|c|c|c|c|c|c|c|}
\hline \multirow[b]{2}{*}{ Taxa } & \multicolumn{2}{|l|}{ May } & \multicolumn{2}{|l|}{ July } & \multicolumn{2}{|c|}{ October } & \multicolumn{2}{|c|}{ February } \\
\hline & Abundance & $\% \mathrm{~F}$ & Abundance & $\% \mathrm{~F}$ & Abundance & $\% \mathrm{~F}$ & Abundance & $\% \mathrm{~F}$ \\
\hline \multicolumn{9}{|l|}{ Elopidae } \\
\hline Elops affinis & & & & & 20 & 11.1 & & \\
\hline \multicolumn{9}{|l|}{ Albulidae } \\
\hline Albula type 1 & & & & & 14 & 11.1 & & \\
\hline \multicolumn{9}{|l|}{ Muraenidae } \\
\hline Muraenidae type 1 & & & & & 4 & 11.1 & & \\
\hline \multicolumn{9}{|l|}{ Ophichthidae } \\
\hline Ophichthidae type 2 & & & & & 21 & 22.2 & & \\
\hline Ophichthus zophochir & & & & & 25 & 11.1 & & \\
\hline Ophichthus type 1 & & & & & 8 & 11.1 & & \\
\hline Myrophis vafer & & & & & 12 & 11.1 & & \\
\hline \multicolumn{9}{|l|}{ Derichthyidae } \\
\hline Derichthyidae type 1 & & & & & 6 & 11.1 & & \\
\hline \multicolumn{9}{|l|}{ Nemichthyidae } \\
\hline Nemichthyidae type 2 & & & & & 4 & 11.1 & & \\
\hline \multicolumn{9}{|l|}{ Congridae } \\
\hline Congridae type 1 & & & & & 8 & 11.1 & & \\
\hline Heteroconger digueti & & & & & 4 & 11.1 & & \\
\hline Ariosoma gilberti & & & & & 18 & 22.2 & & \\
\hline Chiloconger obtusus & & & & & 8 & 11.1 & & \\
\hline Paraconger californiensis & & & & & 14 & 11.1 & & \\
\hline \multicolumn{9}{|l|}{ Nettastomatidae } \\
\hline Hoplunnis sicarius & 13 & 12.5 & & & & & & \\
\hline \multicolumn{9}{|l|}{ Serrivomeridae } \\
\hline Serrivomeridae type 1 & & & & & 5 & 11.1 & & \\
\hline \multicolumn{9}{|l|}{ Cyematidae } \\
\hline Cyematidae type 1 & & & & & 52 & 33.3 & & \\
\hline Cyematidae type 2 & & & & & 17 & 11.1 & & \\
\hline \multicolumn{9}{|l|}{ Clupeidae } \\
\hline Etrumeus teres & & & & & & & 20 & 11.1 \\
\hline Harengula thrissina & 134 & 37.5 & 5 & 11.1 & 15 & 11.1 & & \\
\hline Opisthonema spp. & 433 & 62.5 & 113 & 66.7 & & & & \\
\hline Sardinops sagax & & & & & & & 486 & 44.4 \\
\hline \multicolumn{9}{|l|}{ Engraulidae } \\
\hline Engraulidae & & & 8 & 11.1 & & & & \\
\hline Engraulis mordax & & & & & & & 56 & 11.1 \\
\hline Bathylagidae & & & & & & & & \\
\hline Leuroglossus stilbius & & & & & & & 188 & 44.4 \\
\hline Phosichthyidae & & & & & & & & \\
\hline Vinciguerria lucetia & 4,100 & 75 & 2,060 & 77.8 & 1,648 & 100 & 343 & 77.8 \\
\hline Stomiidae & & & & & & & & \\
\hline Stomias atriventer & & & & & & & 6 & 11.1 \\
\hline Aulopodidae & & & & & & & & \\
\hline Aulopus bajacali & & & & & 154 & 55.6 & 48 & 22.2 \\
\hline Scopelarchidae & & & & & & & & \\
\hline Scopelarchoides nicholsi & 11 & 12.5 & 9 & 11.1 & 25 & 22.2 & & \\
\hline Synodontidae & & & & & & & & \\
\hline Synodus lucioceps & & & & & 43 & 22.2 & & \\
\hline Myctophidae & & & & & & & & \\
\hline Diaphus pacificus & & & & & 88 & 33.3 & 9 & 11.1 \\
\hline Lampanyctus parvicauda & 7 & 12.5 & & & 7 & 11.1 & & \\
\hline Triphoturus mexicanus & 136 & 75 & 1,833 & 88.9 & 421 & 88.9 & 29 & 22.2 \\
\hline Benthosema panamense & & & & & 1,451 & 100 & & \\
\hline
\end{tabular}


Appendix (continued)

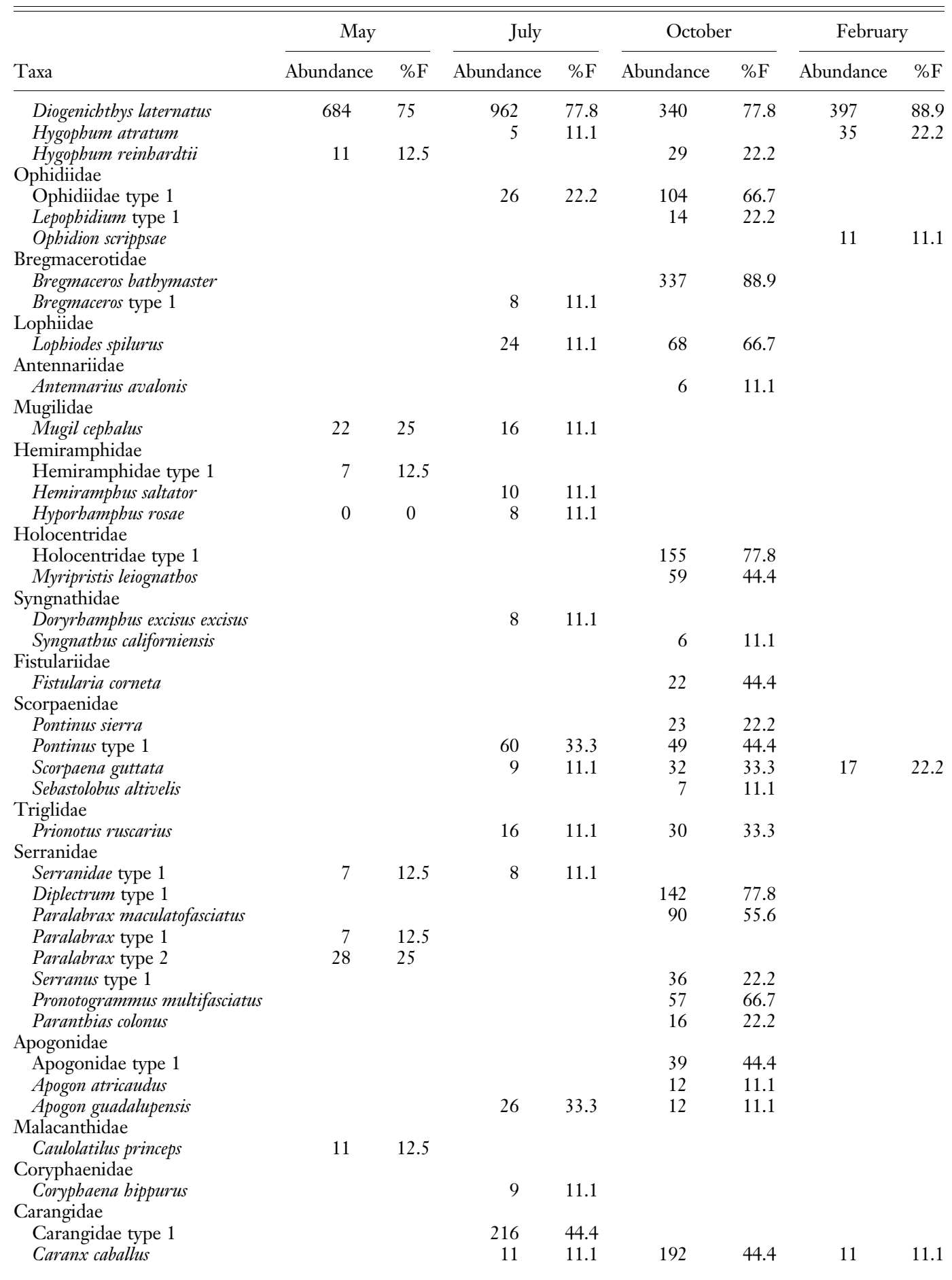


Appendix (continued)

\begin{tabular}{|c|c|c|c|c|c|c|c|c|}
\hline \multirow[b]{2}{*}{ Taxa } & \multicolumn{2}{|l|}{ May } & \multicolumn{2}{|l|}{ July } & \multicolumn{2}{|c|}{ October } & \multicolumn{2}{|c|}{ February } \\
\hline & Abundance & $\% \mathrm{~F}$ & Abundance & $\% \mathrm{~F}$ & Abundance & $\% \mathrm{~F}$ & Abundance & $\% \mathrm{~F}$ \\
\hline Selar crumenopbthalmus & 95 & 37.5 & 31 & 33.3 & & & & \\
\hline Selene peruviana & & & & & 7 & 11.1 & & \\
\hline Trachurus symmetricus & & & & & 42 & 55.6 & & \\
\hline \multicolumn{9}{|l|}{ Lutjanidae } \\
\hline Lutjanus peru & & & & & 39 & 44.4 & & \\
\hline \multicolumn{9}{|l|}{ Gerreidae } \\
\hline Eucinostomus dowii & & & 16 & 11.1 & & & & \\
\hline Diapterus peruvianus & 6 & 12.5 & 42 & 33.3 & & & & \\
\hline \multicolumn{9}{|l|}{ Haemulidae } \\
\hline Haemulidae type 1 & & & 9 & 11.1 & & & & \\
\hline Anisotremus davidsonii & & & 55 & 44.4 & & & & \\
\hline Calamus brachysomus & 68 & 12.5 & & & & & & \\
\hline \multicolumn{9}{|l|}{ Sciaenidae } \\
\hline Sciaenidae type 1 & & & 19 & 11.1 & & & & \\
\hline Roncador stearnsii & & & & & 26 & 44.4 & & \\
\hline \multicolumn{9}{|l|}{ Mullidae } \\
\hline Mulloidichthys dentatus & & & & & 41 & 44.4 & & \\
\hline \multicolumn{9}{|l|}{ Chaetodontidae } \\
\hline Chaetodon bumeralis & & & & & 83 & 77.8 & & \\
\hline \multicolumn{9}{|l|}{ Cirrhitidae } \\
\hline Cirrbitichtbys oxycephalus & & & & & 17 & 33.3 & & \\
\hline \multicolumn{9}{|l|}{ Pomacentridae } \\
\hline Pomacentridae type 1 & 11 & 12.5 & & & 20 & 22.2 & & \\
\hline Pomacentridae type 2 & & & 24 & 33.3 & & & & \\
\hline Chromis punctipinnis & & & & & 15 & 11.1 & & \\
\hline Abudefduf troschelii & 162 & 37.5 & 63 & 33.3 & 4 & 11.1 & & \\
\hline Hypsypops rubicundus & & & & & 12 & 22.2 & & \\
\hline Stegastes rectifraenum & 97 & 25 & 38 & 22.2 & & & & \\
\hline \multicolumn{9}{|l|}{ Labridae } \\
\hline Halichoeres semicinctus & & & & & 24 & 33.3 & & \\
\hline Iniistius pavo & & & & & 8 & 11.1 & & \\
\hline Thalassoma type 1 & & & 5 & 11.1 & & & & \\
\hline Xyrichtys mundiceps & & & & & 18 & 11.1 & & \\
\hline \multicolumn{9}{|l|}{ Bleniidae } \\
\hline Blenniidae type 1 & & & 5 & 11.1 & & & & \\
\hline Opbioblennius steindacbneri & 15 & 12.5 & & & 23 & 22.2 & & \\
\hline \multicolumn{9}{|l|}{ Labrisomidae } \\
\hline Labrisomus xanti & 43 & 25 & & & & & & \\
\hline \multicolumn{9}{|l|}{ Eleotridae } \\
\hline Eleotris picta & & & 32 & 22.2 & 70 & 55.6 & & \\
\hline Erotelis armiger & & & & & 4 & 11.1 & & \\
\hline Gobiidae & & & & & & & & \\
\hline Ctenogobius sagittula & & & & & 15 & 22.2 & & \\
\hline Gobulus crescentalis & 43 & 12.5 & & & 7 & 11.1 & & \\
\hline Lytbrypnus dalli & & & 8 & 11.1 & 14 & 22.2 & & \\
\hline Microdesmidae & & & & & & & & \\
\hline Clarkichthys bilineatus & & & & & 8 & 11.1 & & \\
\hline Sphyraenidae & & & & & & & & \\
\hline Sphyraena ensis & & & 17 & 22.2 & & & & \\
\hline Trichiuridae & & & & & & & & \\
\hline Lepidopus fitchi & & & & & 109 & 44.4 & & \\
\hline Scombridae & & & & & & & & \\
\hline Scomber japonicus & & & & & & & 22 & 22.2 \\
\hline Auxis spp. & 130 & 37.5 & 183 & 44.4 & 46 & 55.6 & & \\
\hline
\end{tabular}


Appendix (continued)

\begin{tabular}{|c|c|c|c|c|c|c|c|c|}
\hline \multirow[b]{2}{*}{ Taxa } & \multicolumn{2}{|l|}{ May } & \multicolumn{2}{|l|}{ July } & \multicolumn{2}{|c|}{ October } & \multicolumn{2}{|c|}{ February } \\
\hline & Abundance & $\% \mathrm{~F}$ & Abundance & $\% \mathrm{~F}$ & Abundance & $\% \mathrm{~F}$ & Abundance & $\% \mathrm{~F}$ \\
\hline \multicolumn{9}{|l|}{ Nomeidae } \\
\hline Cubiceps pauciradiatus & & & & & 7 & 11.1 & & \\
\hline \multicolumn{9}{|l|}{ Paralichthyidae } \\
\hline Citharichtbys platophrys & & & & & 15 & 11.1 & & \\
\hline Citharichthys sordidus & & & 9 & 11.1 & & & & \\
\hline Etropus crossotus & 8 & 12.5 & 24 & 33.3 & 12 & 22.2 & & \\
\hline Etropus type 1 & & & & & 8 & 11.1 & & \\
\hline Syacium ovale & & & 24 & 33.3 & 68 & 77.8 & & \\
\hline Hippoglossina stomata & & & & & 16 & 11.1 & & \\
\hline \multicolumn{9}{|l|}{ Bothidae } \\
\hline Bothus leopardinus & & & 46 & 22.2 & 30 & 33.3 & & \\
\hline Monolene asaedai & & & & & 12 & 22.2 & & \\
\hline \multicolumn{9}{|l|}{ Cynoglossidae } \\
\hline Symphurus type 1 & & & 24 & 33.3 & & & & \\
\hline Symphurus type 2 & & & & & 21 & 22.2 & & \\
\hline Symphurus williamsi & & & 10 & 11.1 & 17 & 22.2 & & \\
\hline \multicolumn{9}{|l|}{ Balistidae } \\
\hline Balistes polylepis & & & 28 & 22.2 & 8 & 11.1 & & \\
\hline \multicolumn{9}{|l|}{ Monacanthidae } \\
\hline Aluterus scriptus & & & & & 8 & 11.1 & & \\
\hline \multicolumn{9}{|l|}{ Tetraodontidae } \\
\hline Sphoeroides annulatus & 21 & 12.5 & & & & & & \\
\hline Sphoeroides lobatus & & & & 0 & & & & \\
\hline \multicolumn{9}{|l|}{ Diodontidae } \\
\hline Diodon bolocanthus & & & & & 94 & 66.7 & & \\
\hline
\end{tabular}

Note: \%F, percentage of occurrence; abundance is expressed as number of larvae per $10 \mathrm{~m}^{2}$; type is used to denote larvae not described in the literature. 